\title{
LARVICIDAL AND REPELLENT ACTIVITY OF LAGENARIA SICERARIA (CUCURBITACEAE) EXTRACTS AGAINST THE HOUSE FLY: MUSCA DOMESTICA (DIPTERA: MUSCIDAE) By
}

\author{
MOSTAFA I. HASSAN, AHMED S. BREAM*, AHMED Z.I. SHEHATA \\ and HOSSAM A. AHMED
}

Department of Zoology, Faculty of Science, Al-Azhar University, Nasr City, Cairo, Egypt ( ${ }^{\star}$ Correspondence:ahmedzeinhom00@gmail.com)

\section{Abstract}

The present study performed at evaluating the potency of methanol, acetone, chloroform and petroleum ether extracts of Lagenaria siceraria leaves against the $3^{\text {rd }}$ instar larvae of the housefly, Musca domestica (Diptera: Muscidae) which consider as a diseases vector. The repellent efficacy of the prepared plant extracts against $M$. domestica adults was examined. All plant extracts showed a larvicidal activity against the $3^{\text {rd }}$ instar larvae of $M$. domestica larvae; however, the petroleum ether extract was found that to be the more effective than chloroform, acetone and methanol extracts. The $\mathrm{LC}_{50}$ values of methanol, acetone, chloroform and petroleum ether extracts recorded 468.5, 432.1, 433.8 and 101.4ppm; respectively. As well, at the $\mathrm{LC}_{50}$ values of the tested extracts exhibited repellent activity against $M$. domestica adults. The effective plant extract that exhibited high antifeedant or repellency action was petroleum ether extract as compared to chloroform, acetone and methanol extracts. These results demonstrated that methanol, acetone, chloroform and petroleum ether extracts of $L$. siceraria leaves can be used as pest control even in their crude form. These results may provide an opportunity to develop alternatives to costly organic pesticides with some available cheap plants which are usually safe to the environment and to living organisms.

Keys words: Larvicidal, Repellent, $M$. domestica, Plant extract, $L$. siceraria

\section{Introduction}

Vector borne diseases cause a major threat to most of the developing countries in the tropical and subtropical regions; they caused millions of death cases in these regions annually. The house fly, Musca domestica L. is a pest of medical importance that prevails mostly in unhygienic environmental conditions and thus indicates to some extent the ecological status of that area (Morey 2016). The house fly, $M$. domestica is a serious pest to livestock and a public health pest that acts as a transmitter of many human and animal diseases (Emerson et al, 1999; Douglass and Jesse, 2002; Mian et al, 2002).Adult houseflies have been shown to transmit pathogens by their sponging mouthparts, through vomiting, on their body and leg hairs, on the sticky parts of the feet and through the intestinal tract, thereby contaminating food and propagating diseases (De Jesús et al, 2004). Several approaches were extensively used to control the threat posed by the house fly, $M$. domestica.

Over the past years, synthetic insecticides were introduced but although these are effective, the fly tends to develop resistance to such products (Jirakanjanakit et al, 2007). Aside from being costly, the use of synthetic insecticides generates problems such as; environmental pollution and toxic side effects to humans (Sarwar et al, 2009). This imposes a need for other alternative methods which are efficient, economic and environmentally safe. Botanical derivatives materialize as a possible larvicides, pupicides, oviposition deterrents, antifeedants and repellent agents against $M$. domestica adults (Fouda et al, 2017).

The present study aimed at evaluating the potency of methanol, acetone, chloroform and petroleum ether extracts of Lagenaria siceraria leaves against $3^{\text {rd }}$ instar larvae of the housefly, Musca domestica (Diptera: Muscidae) a mechanical diseases vector.

\section{Materials and Methods}

Musca domestica culture: The housefly, Musca domestica were reared and maintained continuously for several generations in Medical Entomology Insectary, Zoology 
Department, Faculty of Science, Al-Azhar University (Bream and Abd Elghafar, 2003).

Collection and extraction of plant materials: Lagenaria siceraria was collected from Al-Sharkeya Governorate were left to dry away from sun rays at room temperature $\left(27 \pm 2^{\circ} \mathrm{C}\right)$ for 5 to 10 days and pulverized to powder separately in a hammer mill. The extraction was performed using methanol, acetone, chloroform and petroleum ether solvents. One hundred grams of powder from L. siceraria leaves for each solvent separately were extracted using $300 \mathrm{ml}$ of methanol, acetone, chloroform and petroleum ether at room temperature. After $24 \mathrm{~h}$., the supernatants were decanted, filtrated through the Whatman filter paper (No. 5) and dried in a rotary evaporator at $40^{\circ} \mathrm{C}$ for (2-3hours) for methanol and (40-60minutes) for the other solvents. The dry extracts were weighed and kept at $-4^{\circ} \mathrm{C}$ till using for experiments.

Larvicidal activity: The tested material of the methanol extracts was dissolved in $0.1 \mathrm{ml}$ of methanol, while the tested material of acetone, chloroform and petroleum ether extracts was dissolved in 2drop of Tween ${ }_{80}$ as emulsifier to facilitate the dissolving oils of tested material in $250 \mathrm{ml}$ water. Larval artificial diet was mixed with different concentrations of each concerned extract to detect mortality percent. Then, twenty five of third $3^{\text {rd }}$ instar larvae were put immediately into plastic cups contained media mixed with different concentrations of extracts. Three replicates were usually used for each tested concentration. All plastic cups were incubated under controlled conditions of temperature $27 \pm 2^{\circ} \mathrm{C}$, relative humidity $70-75 \%$ and 12-12 light-dark regime. Control larvae received $0.1 \mathrm{ml}$ of methanol or 2 drops of Tween 80 in $100 \mathrm{ml}$ water. Mortality was recorded daily and dead larvae and pupae were removed daily.

Larval mortality percent was estimated using the following equation (Briggs 1960): larval mortality $\%=\mathrm{A}-\mathrm{B} / \mathrm{A} \times 100$ (where: $\mathrm{A}$ $=$ number of tested larvae, $\mathrm{B}=$ number of tested pupa). Pupation rate was estimated using the following equation: Pupation $\%=$ A / B $\times 100$ (where: $A=$ number of pupae, $B$ $=$ number of tested larvae). The pupal mortality percent was estimated using the following equation: Pupal mortality $\%=\mathrm{A}$ $\mathrm{B} / \mathrm{A} \times 100$ (where: $\mathrm{A}=$ number of produced pupae, $\mathrm{B}=$ number of observed adults).

Adult emergence of males and females were counted and calculated using the following equation: Adult emergence $\%=$ $\mathrm{A} / \mathrm{B} \times 100$ (where: $\mathrm{A}=$ number of emerged adults, $\mathrm{B}=$ number of tested pupae). All values calculated as mean $\pm \mathrm{SD}$.

Antifeedant and repellent activity: Standard cages $(20 \times 20 \times 20 \mathrm{~cm})$ were used to test the repellent activity of plant extracts. Cotton pieces soaked in $10 \%$ sucrose solution from each concentration added to the wooden cages containing 40 starved individuals (5-7 d-old) for three hours. Control tests were carried out alongside with the treatments using cotton pieces soaked in $10 \%$ sucrose solution with 2 drops of methanol or Tween80. Each test was repeated three times to get a mean value of repellent. Repellency $\%$ was calculated (Abbott, 1925):

Repellency $\%=[\% \mathrm{~A}-\% \mathrm{~B} / 100-\% \mathrm{~B}] \times 100$, Where: $\mathrm{A}=$ unfed treated females $\%, \mathrm{~B}=$ unfed control females\%.

Statistical analysis: Data was carried out (lentner et al, 1982). LC L $_{50}$ was calculated using multiple linear regressions (Finney 1971).

\section{Results}

Methanol extract of Leaves: The biological activity of methanol extract of Lagenaria siceraria (leaves) against the $3^{\text {rd }}$ instar larvae of Musca domestica is shown in table (1). The highest larval mortality (100.0\%) was caused by the concentration 1200ppm and the lowest mortality percent $(26.7 \%)$ was caused by the lowest concentration (200ppm) compared to $5.3 \%$ for the untreated larvae. The larval treatment by methanol extract of $L$. siceraria (leaves) prolonged the larval duration, where it recorded 3.6 \pm 0.14 , $3.2 \pm 0.17, \quad 2.9 \pm 0.21, \quad 2.8 \pm 0.10 \quad \& \quad 2.5 \pm 0.15$ days at $1000,800,600,400 \& 200 p p m$; re- 
spectively vs. $2.2 \pm 0.17$ days for control group.

A reduction in pupation percent was observed, where it recorded 6.7, 24.0, 37.3, 54.7 and $73.3 \%$ at concentrations: 1200 , $1000,800,600 \& 400 \mathrm{ppm}$, respectively, compared to $94.7 \%$ for untreated group. The lethal effect of methanol extract of $L$. siceraria (leaves) extended to pupal stage at all concentrations use $(1200,1000,800,600$, $400 \& 200 \mathrm{ppm})$, where pupal mortality was 83.5, 61.3, 42.3, $42.0 \& 34.0 \%$; respectively, vs. $15.7 \%$ for the control. The mean pupal duration was significantly $(\mathrm{P}<0.001)$ affected at the first three concentrations $(800,600$ and 400ppm), recorded 5.6 $\pm 0.12,5.4 \pm 0.15$ $\& 4.9 \pm 0.10$ days compared to $4.2 \pm 0.20$ days for untreated group, with a remarkable reduction in adult emergence percent, recorded $16.5,38.7,57.7,58.0 \& 66.0 \%$ at 1000 , $800,600,400 \& 200 \mathrm{ppm}$, respectively, compared to $84.3 \%$ for untreated group. Growth index for larvae and pupae decreased to 1.7 at the concentration 1000ppm. But, increased to $7.5 \& 9.3$ at lowest two concentrations (400 \& 200ppm), respectively, compared to 12.8 for untreated group (Tab. 1).

Acetone extract of Leaves: The biological activity of acetone extract of $L$. siceraria (leaves) against $3^{\text {rd }}$ instar larvae of $M$. domestica are shown in table (2). The highest concentration $(1000 \mathrm{ppm})$ caused complete larval mortality (100.0\%); meanwhile lowest concentration (200ppm) caused larval mortality percent of $25.3 \%$; while at concentration: $800,600 \& 400$ ppm the mortality percent was $89.3,69.3 \& 46.7 \%$, respectively, compared to $9.3 \%$ for the control group. The mean larval duration was prolonged, where it record $3.8 \pm 0.26,3.2 \pm 0.20,3.0 \pm 0.15$ \& $2.6 \pm 0.12$ days at the concentrations 800,600 , $400 \& 200 \mathrm{ppm}$; respectively, compared to $2.4 \pm 0.22$ days for the untreated group.

The pupation percent varied from $74.7 \%$ at the lowest concentration (200ppm) to 53.3, $30.7 \& 10.7 \%$ at the concentrations 400,600 and $800 \mathrm{ppm}$, respectively, vs. $90.7 \%$ for the control group. The pupal mortality percent was $66.7 \& 37.7 \%$ at concentrations 800 and $200 \mathrm{ppm}$; respectively compared to $19.0 \%$ for control group. The mean pupal duration was significantly $(\mathrm{P}<0.001)$ affected at the highest concentration (800ppm), where it recorded $5.3 \pm 0.37$ days compared with $4.1 \pm 0.14$ days for the control group. The adult emergence $\%$ was recorded $33.3,37.3$, $49.7 \& 62.3$ at the concentrations 800,600 , $400 \& 200 \mathrm{ppm}$, respectively compared to control group (81.0\%). The growth index for larvae and pupae was unaffected by acetone extract of L siceraria (leaves) at all concentrations used as compared with the untreated group (Tab. 2).

Chloroform extract of Leaves: The biological activity of chloroform extract of $L$. siceraria (leaves) against $\mathrm{t}^{\text {rd }}$ instar larvae of $M$. domestica. The highest concentration (1200ppm) caused complete larval mortality; meanwhile, lowest concentration (200 ppm) caused a larval mortality percent of $25.3 \%$ compared to $10.7 \%$ for the control group. Mean larval duration was $3.7 \pm 0.07$, $3.2 \pm 0.26,3.0 \pm 0.05 \& 2.5 \pm 0.10$ days at concentrations 800, 600, $400 \& 200 \mathrm{ppm}$, respectively, compared to $2.0 \pm 0.15$ days for untreated group.

The pupation percent increased as concentration decreased from $1.3 \%$ at highest concentration (1000ppm) to $74.7 \%$ at lowest concentration $(200 \mathrm{ppm})$ vs. $89.3 \%$ for control group. Chloroform extract of $L$. siceraria (leaves) exhibited a great effect on the pupae resulted from treated larvae. The pupal mortality\% recorded 100.0, 100.0, 83.5, $60.0,44.7 \& 37.7$ at the concentrations $1200,1000,800,600,400 \& 200$ ppm, respectively, compared to $16.3 \%$ for control group. Mean pupal duration was significantly $(\mathrm{P}<0.05)$ affected at all concentrations used.

Adult emergence \% recorded $62.3 \%$ at concentration (200ppm). Value decreased to $16.5 \%$ at concentration $(800 \mathrm{ppm})$ compared to control group $(83.7 \%)$. A highly retarded effect on growth occurred. Growth index recorded $1.7,4.6,6.7 \& 8.1$ at concentrations 
$800,600,400 \& 200 \mathrm{ppm}$, respectively vs. 12.7 for untreated group (Tab. 3).

Petroleum ether extract of Leaves: The biological activity of petroleum ether extract of $L$. siceraria (leaves) against the $3^{\text {rd }}$ instar larvae of $M$. domestica. Complete larval mortality (100.0\%) attained at the highest concentration $(250 \mathrm{ppm})$, meanwhile the lowest value $(25.3 \%)$ was occurred at the lowest concentration (50ppm) compared to $8.0 \%$ for the control group. The mean larval duration was insignificantly $(\mathrm{P}>0.05)$ affected at the lowest concentration used (50ppm), where the larval duration was $2.6 \pm 0.25$ days vs. $2.1 \pm 0.29$ days for control group. The pupation percentage of the treated larvae decreased as the concentration increased, recorded $74.7,50.7,24.0 \& 6.7$ at concentrations 50, 100, $150 \& 200 \mathrm{ppm}$, respectively, compared to $92.0 \%$ pupation for the controls. Mean pupal duration was significantly
$(\mathrm{P}<0.05)$ affected by all concentrations used. The growth index recorded 6.0, 3.2, $6.9 \&$ $9.1200,150,100 \& 50 \mathrm{ppm}$, respectively vs. 13.3 for control group (Tab. 4).

The toxicity values of methanol, acetone, chloroform and petroleum ether extracts of $L$. siceraria (leaves) based on $\mathrm{LC}_{50}$ values in a descending order was Petroleum ether extract > Chloroform extract > Acetone extract $>$ Methanol extract (Tab. 5, Fig. 1) .

Antifeedant and repellent activity of tested plant extracts on $M$. domestica adults: The methanol, acetone, chloroform and petroleum ether extracts of $L$. siceraria (leaves) gave a variable degree of repellency Potent repellency $(86.5 \%)$ obtained by petroleum ether extract by $3 \mathrm{~h}$ post treatment, methanol, acetone and chloroform extracts exhibited $67.6,73.0 \& 83.8 \%$ repellency action, respectively, within 3 hours post treatment (Tab. 6).

Table 1: Effect of methanol extract of L. siceraria (leaves) on some biological aspects of M. domestica.

\begin{tabular}{|c|c|c|c|c|c|c|c|c|}
\hline $\begin{array}{l}\text { Conc. } \\
\text { ppm }\end{array}$ & $\begin{array}{l}\text { Larval mort. } \\
\%\end{array}$ & $\begin{array}{l}\text { Larval } \\
\text { Period }\end{array}$ & $\begin{array}{l}\text { Pupa- } \\
\text { tion \% }\end{array}$ & $\begin{array}{l}\text { Pupal } \\
\text { Mort. \% }\end{array}$ & $\begin{array}{l}\text { Pupal } \\
\text { Period }\end{array}$ & $\begin{array}{l}\text { Emergence } \\
\%\end{array}$ & $\begin{array}{l}\text { Developmental } \\
\text { Period }\end{array}$ & $\begin{array}{l}\text { Growth } \\
\text { Index }\end{array}$ \\
\hline 1200 & 100.0 & - & - & - & - & - & - & - \\
\hline 1000 & 93.3 & $3.6 \pm 0.14^{\mathrm{d}}$ & 6.7 & 83.5 & $6.0 \pm 0.0$ & 16.5 & $9.6 \pm 0.14^{\mathrm{d}}$ & 1.7 \\
\hline 800 & 76.0 & $3.2 \pm 0.17^{\mathrm{d}}$ & 24.0 & 61.3 & $5.6 \pm 0.12^{\mathrm{d}}$ & 38.7 & $8.8 \pm 0.29^{\mathrm{d}}$ & 4.4 \\
\hline 600 & 62.7 & $2.9 \pm 0.21^{\mathrm{c}}$ & 37.3 & 42.3 & $5.4 \pm 0.15^{\mathrm{d}}$ & 57.7 & $8.3 \pm 0.36^{\mathrm{d}}$ & 7.0 \\
\hline 400 & 45.3 & $2.8 \pm 0.10^{c}$ & 54.7 & 42.0 & $4.9 \pm 0.10^{\mathrm{d}}$ & 58.0 & $7.7 \pm 0.20^{\mathrm{c}}$ & 7.5 \\
\hline
\end{tabular}

No. of tested larvae $=25$ per replicate; Conc. $=$ Concentration; ppm $=$ particle per million; $\mathrm{SD}=$ standard deviation; mort. $=$ mortality; $\mathrm{a}=$ non-significant $(\mathrm{P}>0.05) ; \mathrm{b}=$ significant $(\mathrm{P}<0.05) ; \mathrm{c}=$ highly significant $(\mathrm{P}<0.01) ; \mathrm{d}=$ very highly significant $(\mathrm{P}<0.001)$.

Table 2: Effect of acetone extract of L. siceraria (leaves) on some biological aspects of M. domestica.

\begin{tabular}{|c|c|c|c|c|c|c|c|c|}
\hline $\begin{array}{l}\text { Conc. } \\
\text { ppm }\end{array}$ & $\begin{array}{l}\text { Larval } \\
\text { mort. \% }\end{array}$ & $\begin{array}{l}\text { Larval } \\
\text { Period }\end{array}$ & $\begin{array}{l}\text { Pupa- } \\
\text { tion } \%\end{array}$ & $\begin{array}{l}\text { Pupal } \\
\text { Mort. \% }\end{array}$ & $\begin{array}{l}\text { Pupal } \\
\text { Period }\end{array}$ & $\begin{array}{c}\text { Emer- } \\
\text { gence } \\
\%\end{array}$ & $\begin{array}{c}\text { Developmental } \\
\text { Period }\end{array}$ & $\begin{array}{l}\text { Growth } \\
\text { Index }\end{array}$ \\
\hline 1000 & 100.0 & - & - & - & - & - & - & - \\
\hline 800 & 89.3 & $3.8 \pm 0.26^{\mathrm{d}}$ & 10.7 & 66.7 & $5.3 \pm 0.37^{d}$ & 33.3 & $9.1 \pm 0.63^{d}$ & 3.7 \\
\hline 600 & 69.3 & $3.2 \pm 0.20^{\mathrm{c}}$ & 30.7 & 62.7 & $4.9 \pm 0.16^{b}$ & 37.3 & $8.1 \pm 0.36^{\mathrm{c}}$ & 4.6 \\
\hline 400 & 46.7 & $3.0 \pm 0.15^{b}$ & 53.3 & 50.3 & $4.7 \pm 0.21^{\mathrm{a}}$ & 49.7 & $7.7 \pm 0.36^{b}$ & 6.5 \\
\hline Control & 9.3 & $2.4 \pm 0.22^{\mathrm{a}}$ & 90.7 & 19.0 & $4.1 \pm 0.14^{\mathrm{a}}$ & 81.0 & $6.5 \pm 0.36^{\mathrm{a}}$ & 12.5 \\
\hline
\end{tabular}

Table 3: Effect of chloroform extract of L. siceraria (leaves) on some biological aspects of M. domestica.

\begin{tabular}{|l|l|l|l|l|l|l|l|l|}
\hline $\begin{array}{l}\text { Conc. } \\
\text { ppm }\end{array}$ & $\begin{array}{l}\text { Larval } \\
\text { mort. } \%\end{array}$ & $\begin{array}{l}\text { Larval } \\
\text { Period }\end{array}$ & $\begin{array}{l}\text { Pupa- } \\
\text { tion \% }\end{array}$ & $\begin{array}{l}\text { Pupal Mort. } \\
\%\end{array}$ & $\begin{array}{l}\text { Pupal } \\
\text { Period }\end{array}$ & $\begin{array}{l}\text { Emer- } \\
\text { gence \% }\end{array}$ & $\begin{array}{l}\text { Develop- } \\
\text { mental } \\
\text { Period }\end{array}$ & $\begin{array}{l}\text { Growth } \\
\text { Index }\end{array}$ \\
\hline 1200 & 100.0 & - & - & - & - & - & - & - \\
\hline 1000 & 98.7 & $4.0 \pm 0.0$ & 1.3 & 100.0 & - & - & - & - \\
\hline 800 & 89.3 & $3.7 \pm 0.07^{\mathrm{d}}$ & 10.7 & 83.5 & $6.2 \pm 0.0$ & 16.5 & $9.9 \pm 0.07^{\mathrm{d}}$ & 1.7 \\
\hline 600 & 68.0 & $3.2 \pm 0.26^{\mathrm{d}}$ & 32.0 & 60.0 & $5.4 \pm 0.15^{\mathrm{d}}$ & 40.0 & $8.6 \pm 0.39^{\mathrm{d}}$ & 4.6 \\
\hline 400 & 45.3 & $3.0 \pm 0.05^{\mathrm{d}}$ & 54.7 & 44.7 & $5.2 \pm 0.23^{\mathrm{d}}$ & 55.3 & $8.2 \pm 0.28^{\mathrm{d}}$ & 6.7 \\
\hline 200 & 25.3 & $2.5 \pm 0.10^{\mathrm{c}}$ & 74.7 & 37.7 & $4.6 \pm 0.17^{\mathrm{b}}$ & 62.3 & $7.7 \pm 0.27^{\mathrm{c}}$ & 8.1 \\
\hline Control & 10.7 & $2.0 \pm 0.15^{\mathrm{a}}$ & 89.3 & 16.3 & $4.1 \pm 0.18^{\mathrm{a}}$ & 83.7 & $6.6 \pm 0.33^{\mathrm{a}}$ & 12.7 \\
\hline
\end{tabular}


Table 4: Effect of petroleum ether extract of L. siceraria (leaves) on some biological aspects of M. domestica

\begin{tabular}{|l|l|l|l|l|l|l|l|l|}
\hline $\begin{array}{l}\text { Conc. } \\
\text { ppm }\end{array}$ & $\begin{array}{l}\text { Larval } \\
\text { mort. \% }\end{array}$ & $\begin{array}{l}\text { Larval } \\
\text { Period }\end{array}$ & $\begin{array}{l}\text { Pupation } \\
\%\end{array}$ & $\begin{array}{l}\text { Pupal } \\
\text { Mort. \% }\end{array}$ & $\begin{array}{l}\text { Pupal } \\
\text { Period }\end{array}$ & $\begin{array}{l}\text { Emer- } \\
\text { gence \% }\end{array}$ & $\begin{array}{l}\text { Developmental } \\
\text { Period }\end{array}$ & $\begin{array}{l}\text { Growth } \\
\text { Index }\end{array}$ \\
\hline 250 & 100.0 & - & - & - & - & - & - & - \\
\hline 200 & 93.3 & $4.2 \pm 0.21^{\mathrm{d}}$ & 6.7 & 41.5 & $5.6 \pm 0.39^{\mathrm{d}}$ & 58.5 & $9.8 \pm 0.70^{\mathrm{d}}$ & 6.0 \\
\hline 150 & 76.0 & $3.5 \pm 0.21^{\mathrm{d}}$ & 24.0 & 72.3 & $5.2 \pm 0.21^{\mathrm{d}}$ & 27.7 & $8.7 \pm 0.34^{\mathrm{d}}$ & 3.2 \\
\hline 100 & 49.3 & $2.9 \pm 0.23^{\mathrm{b}}$ & 50.7 & 49.3 & $4.8 \pm 0.15^{\mathrm{c}}$ & 50.7 & $7.3 \pm 0.42^{\mathrm{b}}$ & 6.9 \\
\hline 50 & 25.3 & $2.6 \pm 0.25^{\mathrm{a}}$ & 74.7 & 35.3 & $4.5 \pm 0.08^{\mathrm{b}}$ & 64.7 & $7.1 \pm 0.16^{\mathrm{a}}$ & 9.1 \\
\hline Control & 8.0 & $2.1 \pm 0.29^{\mathrm{a}}$ & 92.0 & 20.3 & $3.9 \pm 0.11^{\mathrm{a}}$ & 79.7 & $6.0 \pm 0.36^{\mathrm{a}}$ & 13.3 \\
\hline
\end{tabular}

Table 5: Relative efficiency of $L$. siceraria solvents extracts (leaves) against $M$. domestica larvae.

\begin{tabular}{|c|c|c|c|c|c|c|}
\hline \multirow{2}{*}{ Extract } & \multirow{2}{*}{$\begin{array}{l}\mathrm{LC}_{50} \text { value } \\
(\mathrm{ppm})\end{array}$} & \multicolumn{2}{|c|}{ Fed flies } & \multicolumn{2}{|c|}{ Non-fed flies } & \multirow{2}{*}{$\begin{array}{l}\text { Repellency action } \\
(\%)\end{array}$} \\
\hline & & No. & $\%$ & No. & $\%$ & \\
\hline Methanol & 468.5 & 12 & 30.0 & 28 & 70.0 & 67.6 \\
\hline Acetone & 432.1 & 10 & 25.0 & 30 & 75.0 & 73.0 \\
\hline Chloroform & 433.8 & 6 & 15.0 & 34 & 85.0 & 83.8 \\
\hline Petroleum Ether & 101.4 & 5 & 12.5 & 35 & 87.5 & 86.5 \\
\hline Control & 0.0 & 37 & 92.5 & 3 & 7.5 & 0.0 \\
\hline
\end{tabular}

Table 6: $\mathrm{LC}_{50}$ concentration of L. siceraria (leaves) solvents extracts as antifeedant \&repellent for $M$. domestica.

\begin{tabular}{|l|l|l|l|}
\hline Extract & $\mathrm{LC}_{50}(\mathrm{ppm})$ & Slope $(\mathrm{b})$ & Correlation Coefficient $(\mathrm{r})$ \\
\hline Methanol & 468.5 & 0.0748 & 0.9862 \\
\hline Acetone & 432.1 & 0.096 & 0.986 \\
\hline Chloroform & 433.8 & 0.0793 & 0.936 \\
\hline Petroleum ether & 101.4 & 0.3868 & 0.9596 \\
\hline
\end{tabular}

\section{Discussion}

Although Insecticide applications have a high efficiency against the target species, vector control is facing a threat due to the development of resistance to chemical insecticides resulting in rebounding vectorial capacity (Liu et al, 2006). Thus, they are responsible for substantial hazards to a variety of non-target organisms and environment in the form of biomagnification (Gold et al, 2001). The present authors diverted their attention towards plant kingdom, which are ecofriendly and low cost (Madhu et al, 2009). Lagenaria siceraria belongs to family Cucurbitaceae is known to be eco-friendly and are not toxic to vertebrates. Moreover, it is clearly proved that crude or partially purified plant extracts are less expensive and highly efficacious for the control of Musca domestica rather than the purified compounds or extracts (Jang et al, 2002; Cavalcanti et al, 2004). However $L$. siceraria was used for the first time to control M. domesti$c a$.

L. siceraria leaves extract have exerted promising larvicidal effect against $3^{\text {rd }}$ instar larvae of $M$. domestica. Toxicity of these plant extracts was varied according to the plant part, solvent used in extraction and also the concentration of the extract. The larval mortality percent was increased by increasing extract concentration for all plant extracts tested. Based on $\mathrm{LC}_{50}$ values, the petroleum ether extract was the most effective than chloroform, acetone and methanol extracts tested. The effect of tested $L$. siceraria leaves extracts on larval mortality of $M$. domestica was in a harmonious with earlier reports for using plant extracts against the larvae of $M$. domestica. The obtained results are agreed with Begum et al. (2010) for the crude ethanolic leaves extracts of Calotropis procera and Anonna squamosal $\left(\mathrm{LC}_{50}\right.$ values were 282.5 and 550ppm), Begum et al., (2011) for ethanolic extracts of Calotropis procera (seeds) on $3^{\text {rd }}$ instar larvae of $M$. domestica (the $100.0 \%$ mortality was observed at 500ppm), Akhater et al. (2012) for the fresh leaf of milk weed (Calotropise procera) juice against larvae of M. domestica, Sinthusiri et al. (2013) for essential oils from Cinnamomum verum, Myristica fragrans and Syzygium aromaticum against M. domestica, Ogbalu et al. (2014) for the aqueous leaf extract of tobacco (Nicotiana tabacum) on M. domestica 
larvae, Aktar and Islam, (2015) for wholeplant boiled extracts of three indigenous plant species Calotropis procera, Piper longum and Polygonum hydropiper against $M$. domestica, where the $\mathrm{LC}_{50}$ values were

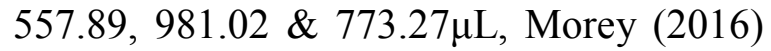
for the crude extracts of Citrus limon and Ocimum basilicum against $M$. domestica with $\mathrm{LC}_{50}$ (110ppm) shown by $O$. basilicum, Carapeto et al., (2017) for two formulations of Amanita muscaria against $M$. domestica with two methods of extraction, where the mean lethal concentration $\left(\mathrm{LC}_{50}\right)$ of aqueous extract from dried, powdered basidiomes (DPB) was approximately 1931.02ppm and the $\mathrm{LC}_{50}$ for the fresh basidiomes liquefied in water (FLB) was about $30 \%$.

Also, similar results were recorded by Fouda et al. (2017) for ethanolic, acetone and petroleum ether extracts of Lantana camara (leaves and stems) against $3^{\text {rd }}$ instar larvae of $M$. domestica, where petroleum ether extract from leaves and stems were more toxic than acetone and ethanolic one.

In the present study, prolongation in larval duration with tested plants was similar to that reported in $M$. domestica by Bakr et al. (2003) an Artemisia monosperma, Conyza dioscoridis, Clerodedron inerme, Clocasia antiqorum, Elkattanet al. (2011) using Lantana camara and Cupressus macrocarpa (leaves) powders. On the other hand, the shortened larval period after treatment agreed with Shaalan et al. (2005) where they treated Aedes aegypti larvae with Callitris glaucophylla. They mentioned that, the larvae developed to pupate faster as their environment increased in toxicity and (Abdel Razik, 2017) of $M$. domestica when treated with two plant crude extracts and three plant volatile oils.

The present results showed the prolongation in pupal duration, similar observation was also recorded on $M$. domestica by Bakr et al. (2003) who used Artemisia monosperma, Conyza dioscoridis, Eichhornia crassipes, Clerodedron inerme, Clocasia antiqorum and Farestia aegyptia. On the contrary, other plants reduced pupal duration such those recorded by Bakr et al. (2003) who used Zygophyllum coccineumon $M$. domestica, Khater and Shalaby, (2008) for Cyperus esculentuson C. pipiens and ElSheikh et al. (2012) for methanolic extract of Tribulus terrestris on the malarial vector Anopheles arabiensis.

The decrease in the percentage of $M$. domestica adult emergence when treated with the tested plant extracts agreed with Khalaf et al., (2009) who recorded a high reduction in Synthesiomyia nudiseta adult emergence after larval treatiment with $C$. macrocarpa and A. officinarum volatile oils, Singh and Kaur (2016) recorded $12.75 \& 25.55 \%$ reduction in $M$. domestica adult emergence by dipping and thin layer technique after treating $3^{\text {rd }}$ larval instar with chloroform extract of Ricinus communis and Olaleyeet al. (2017) reported that, at $15.0 \%$ concentration of Petiveria alliacea, and Fluegga evirosa reduced mean emergence of $M$. domestica adults by $10.0,9.0,11.9,11.9 \& 13.8 \%$.

In the present study, growth index of $M$. domestica was affected by the tested plant extracts as it decreased with the increased concentration of extract. Retardation in growth was induced by different parts of plant tested. This agreed with studies using different plant extracts against some dipteran species as Jeyabalan et al., (2003) for Pelargonium citrosa leaf extracts on Anopheles stephensi, Nathan et al. (2006) for Melia azedarachon A. stephensi, Sharma et al. (2006) where they used Artemisia annua extract against Culex autnauetesctetus and Fouda et al. (2017) used L. camara (leaves and stems) extracts against $M$. domestica.

In the present study tested plant extracts exhibited a various degree of repellency at the concentration $\mathrm{LC}_{50}$ against $M$. domestica and this may reflect the complexity of the chemical composition of their constituents. The petroleum ether extraction of the plant used was more effective in repellent action against $M$. domestica as compared with the chloroform, acetone and methanol extrac- 
tions. These results agreed with Bisseleua et al. (2008) where they used petroleum ether extracts of Griffonia simplicifolia and Zanthoxylum xanthoxyloides against $M$. domestica, ELbermawy et al. (2011) used C. sempervirens, Cupressus macrocarpa, Euphorbia pereskiifolia, pelargonium zonale, $L$. camara, Cyperus rotundus, Acacia nilotica, Simmondsia chinensis, Eucalyptus globulus, Amygdalus communis and Citrus maxima extracts and essential oils against $M$. domestica, Sharma et al. (2011) used ethanolic extracts of Annona squamosa, Artemisia japonica, Artemisia niligirica, Blumea eriantha, Calotropis procera, Hyptis suaveolens, Lavendula bipinnata, Lavendula lawii, Leonotis nepetaefolia and Leucas asper and Ocimum gratissimum against $M$. domestica, Chintalchere et al, (2013) used essential oils of Thymus vulgaris and Eugenia coryophyllus against $M$. domestica, Morey (2016) used the crude extracts of lemon, Citrus limon and basil, Ocimum basilicum against M. domestica and Fouda et al., (2017) used ethanolic, acetone and petroleum ether extracts from leaves and stems of Lantana $\mathrm{ca}$ mara against $M$. domestica.

\section{Conclusion}

The outcome data showed that $L$. siceraria extracts used proved to be $\backslash$ a new promising controlling and repellent agents for $M$. domestica.

\section{References}

Abbott, WS, 1925: A method for computing the effectiveness of an insecticide. J. Econ. Entomol. 18:2651-77.

Abdel Razik, MAA, 2017: Toxicological and developmental effects of selected insecticides, plant volatile oils and plant extracts on house fly, Musca domestica L. IJBMB. 7, 3: 127-37.

Aktar MJ, Islam MS, 2015: An eco-friendly approach to reduce reproductive attributes in the house fly, Musca domestica L. using crude plant extracts .Sc. Acad. J. Biosci. 3, 5:443-51.

Bakr, ME, Nassef, NE, Assar, AA, El-Sobky, MM, Shams EI Din, SA, 2003: Biological and morphological effects of water extracts of some plants on the house fly, Musca domesticavicina
Macq. (Diptera: Muscidae). J. Egypt. Ger. Soc. Zool. 41, E:29-47.

Begum, N, Sharma, B, Pandey, RS, 2010: Evaluation of Insecticidal efficacy of CalotropisProcera and Annona Squamosa ethanol extracts against Musca domestica. J. Bio. Biopest. $1: 1-12$

Begum, N, Sharma, B, Pandey RS, 2011: Toxicity Potential and Anti AChE Activity of Some plant extracts on Musca domestica. J. Biofer. Biopesti. 2, 2:01-6.

Bisseleua, HBD, Gbewonyo, SWK, ObengOfori, D, 2008: Toxicity, growth regulatory and repellent activities of medicinal plant extracts on Musca domestica L. (Diptera: Muscidea). Afr. J. Biot. 7, 24:4635-42.

Bream, AS, Abd Elghafar, A,2003: Certain biochemical changes in the house fly, Musca domestica (L.) larvae as induced by feeding on a diet treated with Tebufenozide (RH- 5992). AlAzhar Bull. Sci., Proc. $5^{\text {th }}$ Int. Sci. Conf., 30919.

Briggs, JN, 1960: Reduction of adult house fly emergence by the effective Bacillus sp. on the development of immature forms. J. Insect Pathol. 2:418-32.

Carapeto, LP, Cárcamo, MC, Duarte, JP, de Melo, LG, Bernardi, E, et al, 2017: Larvicidal efficiency of the fungus Amanita muscaria (Agaricales,Amanitaceae) against Musca domestica (Diptera, Muscidae). Biotemas. 30, 3:79-83. Cavalcanti, ES, Morais, SM, Lima, MA, Santana, EW, 2004: Larvicidal activity of essential oils from Brazilian plants against Ae. aegypti L. Mem. Inst. Oswaldo. Cruz. 99, 5: 541-4.

Chintalchere, JM, Lakare, S, Pandit, SR, 2013: Bioefficacy of essential oils of Thymus vulgaris and Eugenia caryophyllus against house fly, Musca domestica L. An international Quariterly J. life Sci. 8, 3:1029-34.

De Jesús, AJ, Olsen, AR, Bryce, JR, Whiting, RC, 2004: Quantitative contamination and transfer of Escherichia coli from foods by houseflies, Musca domestica L. (Diptera: Muscidae). Int. J. Food Microbiol. 93:259-62.

Douglass, ES, Jesse, C, 2002: Integrated pest management for fly control in Maine dairy farms. Texas Agricultural Extension Service.

El- Sheikh, TMY, Bosly, HMA, Shalaby, N, 2012: Insecticidal and repellent activities of methanolic extract of TribulusterrestrisL. (Zygophyllaceae) against the malarial vector 
Anopheles arabiensis (Diptera: Culicidae). Egypt. Acad. J. Biol. Sci. 5, 2: 13-22.

Elbermawy, SM, Elkattan, NAI, Ahmed, SK, Abdel-Gawad, RM, 2011: Screening for bioactive materials against house fly, Musca domestica L. (Diptera: Muscidae Funct. Plant Sci. Biotechnol. 5, 1:45-51.

Emerson, PM, Lindsay, SW, Walraven, GEL, Faal, H, Bogh, C, et al, 1999: Effect of fly control on trachoma and diarrhea. Lancet 353:14013.

Finney, DJ, 1971: Probit Analysis. Third edition. Cambridge University Press.

Fouda, MA, Hassan, MI, Shehata, AZ, Hasaballah, AI, Gad, ME, 2017:Larvicidal and antifeedant activities of different extracts from leaves and stems of Lantana camara (Verbenaceae) against the housefly, Musca domestica L. Egypt. Acad. J. Biol. Sci. 9, 1:85-98.

Gold, LS, Slone, TH, Ames, BN, Manely, NB, 2001: Pesticide residues in food and cancer risk; a critical analysis. In: Krieger, R. (Ed.), Handbook of Pesticide Toxicology, $2^{\text {nd }}$ ed. Academic Press, San Diego, C.A.

Hanan, BA, 2013: Evaluation of insecticidal activities of Mentha piperta and Lavandula angustifolia essential oils against house fly, Musca domestica L. (Diptera: Muscidae). J. Entomol. Nematol. 5:50-4.

Jang, YS, Baek, BR, Yang, YC, Kim, MK, Lee, HS, 2002: Larvicidal activity of leguminous seeds and grains against Ae. aegypti and $C$. pipiens pallens. J. Am. Mosq. Control. Assoc. 18, 3:210-3.

Jeyabalan, D, Arul, N, Thangamathi, P, 2003: Studies on effects of Pelargonium citrosa leaf extracts on malarial vector, A. stephensi Liston. Bioresour. Technol. 89, 2:185-9.

Jirakanjanakit, NP, Rongnoparut, S, Saegtharatip, T, Chareonviriyaphap, S, Duchon, $\mathrm{C}$ B, et al, 2007: Insecticide susceptib le/resistance status in Aedes (Stegomyia) aegypti and Aedes (Stegomyia) albopictus (Diptera: Culicidae) in Thailand during 2003 - 2005. J. Econ. Entomol. 100, 2:545-50.

Khalaf, AA, Hussein, KT, Shoukry, KK, 2009: Biocidal Activity of two botanical volatile oils against the larvae of Synthesiomyianudiseta (Wulp) (Diptera: Muscidae). Egypt Acad. J. bio. Sci. 2, 1:89-101.

Khater, HF, Shalaby, AA, 2008: Potential of biologically active plant oils to control mosquito larvae (Culex pipiens, Diptera: Culicidae) from an Egyptian locality. Rev. Inst. Med. Trop. S. Paulo. 50, 2:107-12.

Lentner, C, Lentner, C, Wink, A, 1982: Student's t- distribution Tables. In: Scientific Tables Vol. 2; International Medical and Pharmaceutical information, Ciba-Geigy Limited, Basal, Switzerland.

Liu, N, Xu, Q, Zhu, F, Zhang, L, 2006: Pyrethroid resistance in mosquitoes. Insect Sci. 13:159-66.

Madhu, SK, Shaukathb, AK, Vijayanc, VA, 2009: Efficacy of bioactive compounds from Curcuma aromatica against mosquito larvae. Acta Trop. 113:7-11.

Mian, LS, Maag, H, Tacal, JV, 2002: Isolation of Salmonella from muscoid flies at commercial animal establishments in San Bernardino County, California. J. Vector Ecol. 27: 82-5.

Morey, RA, 2016: Evaluation of crude extracts of Citrus limon and Ocimum basilicum against Musca domestica L. http://rutpp.com, 01-4.

Nathan, SS, Savitha, G, George, DK, Narmadha, A, Suganya, L, et al, 2006: Efficacy of Melia azedarach L. extract on the malarial vector A. stephensi Liston (Diptera: Culicidae). Bioresour Technol. 79:1316-23.

Ogbalu, OK, Bobmanuel, RB, Membere, O, 2014: Larvicidal effect of aqueous leaf extract of Tobacco (Nicotiana tabacum) on the third instar larvae of Musca domestica. J. Agri. Vet. Sci. 7, 12:35-40.

Olaleye, T, Muse, WA, Imeh-Nathaniel, A, Nathaniel, TI, 2017: Biological effects of Petiveria alliacea and Flueggaevirosa on the life cycle of a disease vector (Musca domestica). ijpaz. 5, 1:45-51.

Sarwar, M, Ahmad, N, Toufiq, M, 2009: Host plant resistance relationships in chickpea (Cicer arietinum L.) against gram pod borer (Helicoverpa armigera Hubner). Pak J Bot. 3047-52.

Shaalan, EAS, Canyon, DV, Younes, MWF, Abdel Wahab, H, Mansour, AH, 2005: Effects of sub-lethal concentrations of synthetic insecticides and Callitris glaucophylla extracts on the development of Aedes aegypti. J. Vector Ecol. 30, 2:295-8.

Sharma, PP, Pardeshi, AB, Vijigiri D, 2011: Bioactivity of some medicinal plant extracts against Musca domestica L. J. Ecobiotechnol. 3, 9:14-6.

Sharma, p, Mohan, L, Srivastava, CN, 2006: Growth Inhibitory Nature of Artemisia annua extract against Culex autnauetesctetus (Say). J. 
Asia-Pacific Entomol. 9, 4:389-95.

Singh A, Kaur, J, 2016: Toxicity of leaf extracts of Ricinus communis L. (Euphorbiaceace) against the third instar larvae of Musca domestica L. (Diptera: Muscidae). American J. of BioSci. 4, 3/1:5-10.
Sinthusiri, J, Soonwera, M, Boonmeesupmak, P, 2013: Green insecticide from herbal essential oils against house fly, Musca domestica $L$. (Muscidae: Diptera). J. Agri. Technol. 9, 6: 1453-60.

Fig. 1: Regression line of larval mortality of M. domestica treated with different solvents extracts of L. siceraria (leaves).

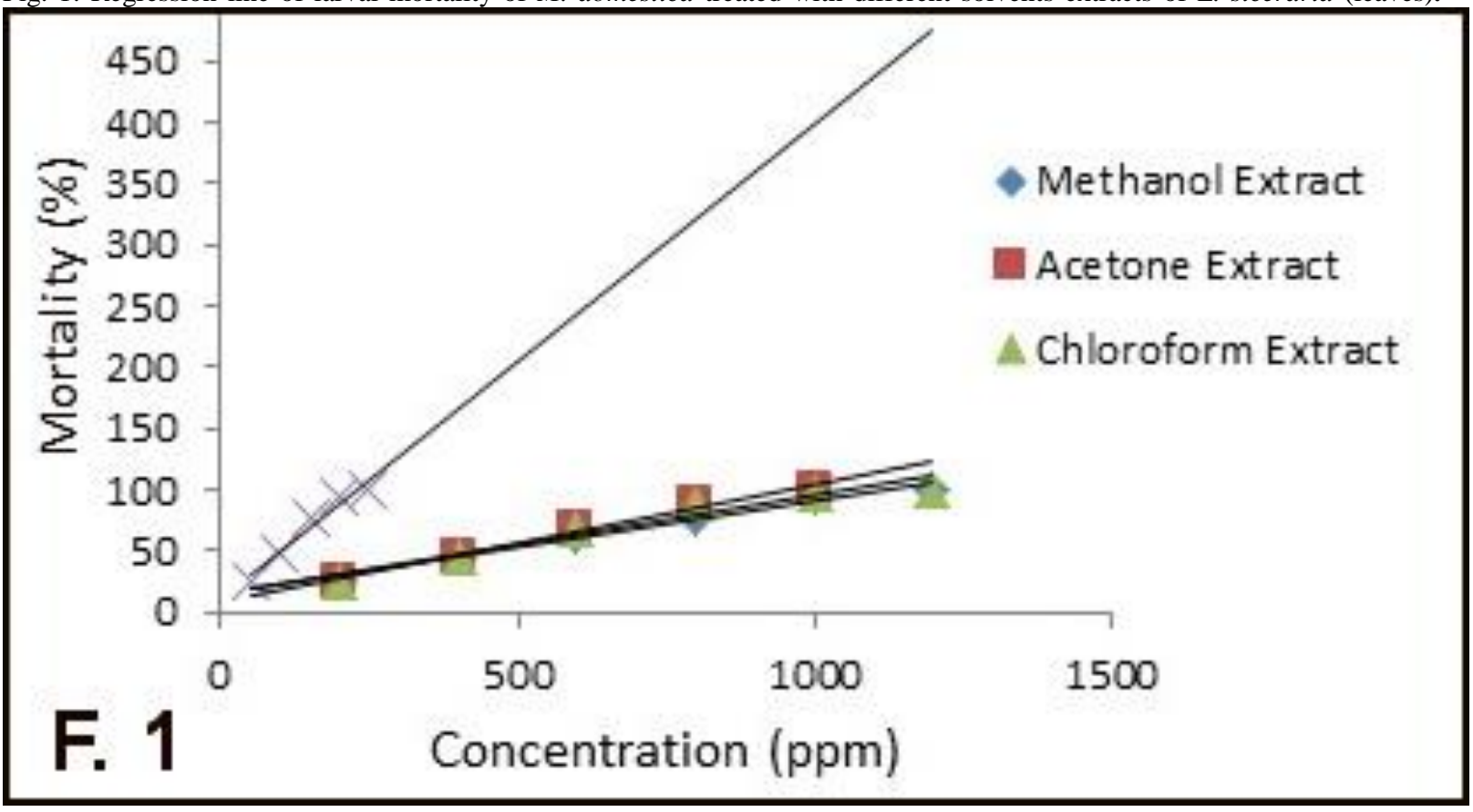

